\title{
Is the Online Friendship Scale Fit for High School Students?
}

\author{
Avin Fadilla Helmi \\ Faculty of Psychology, Universitas Gadjah Mada \\ Submitted 6 July 2020 \\ Accepted 28 August 2020 \\ Published 27 October 2020
}

\begin{abstract}
Online friendship is an inevitable phenomenon especially for young people for which Helmi et al. developed a concept and an online friendship scale with university students as their trial subject. From a developmental perspective, university students are in the early adulthood stage. With the Internet's asynchronous nature and the absence of nonverbal cues, the scale was applied to high school students in this present study. The purpose of this study was to test whether or not the online friendship scale has sound psychometric properties when applied to high school students. The subjects of this study were 214 high school students. The results of the structural equation model analysis met the goodness of fit criteria for construct validity, which include TL, GFT, and RMSEA indices. Its Cronbach's alpha reliability coefficient was also satisfying. A drive to create activities with friends on social media mitigates the lack of non-verbal signs resulting from online communication. This result supports the social enhancement hypothesis. Consequently, Online Friendship Scale can be implemented in adolescence and young adult.
\end{abstract}

Keywords: adolescent; construct validity; online friendship scale; reliability

Friendship has an important meaning for $S M A$ (senior high school) students, because they are in the adolescence period during which they are experiencing socioemotional developments, especially that of self-identity seeking. In this self-exploration process, they may experience worries and anxieties for which they need friends to be there for them to provide support and to whom they can compare themselves with. Besides, friendship also serves to fulfill human needs for welfare and development during childhood and adolescence (Santrock, 2013) and is closely related to positive interpersonal relationships. Friendship is important and meaningful to meet critical aspects in their interpersonal

Address for correspondence: avinpsi@ugm.ac.id life as humans, namely intimacy, support, loyalty, and self-validation (Yeung \& Fung, 2007).

On the other hand, bullying cases quite often appear in the mass media, suggesting that bullying is still rife among young people. For example, in February 2020, several cases of bullying were recorded at school, including a student with special needs in a junior high school Purworejo, Central Java, who was bullied by their friends at school, a 13-year-old student in Malang, East Java, who experienced hand fracture and later had to have their hand amputated as a result of bullying by 7 friends, and a video of bullying to an elementary school student in Batujajar, West Bandung (Wismabrata, 2020). 
These are the two sides of the same coin of the internet presence. The rapid development of information technology has inevitably caused friendships on social networks to flourish. Social Networking Service (SNS) is a bridge for high school students to communicate with their school mates and those from outside their school through various types of media in it. This social networking service provides social media that enable them to present themselves to others (Davis, 2012).

Online friendship is defined as a type of friendship that starts and develops through Computer-Mediated Communication (CMC) (Chan \& Cheng, 2004) in an online social setting including chat rooms, discussion forums, and websites. Online friendship is created in several media that facilitate their users to make friends. These media include Facebook, Twitter, Instagram, WhatsApp, Line, Tumblr, Path, Snapchat, and so on.

Helmi et al. (2017) conducted grounded research on online friendship. Their research findings are described in four ways. The first is the location in the virtual world. The second is the partner of friendship: an individual known from faceto-face interaction, an individual known on social media, or a total stranger. The third is the modality used to exchange messages: a public or private medium. The fourth is the basis of the interaction which is usually characterized by high self-disclosure but not emotionally deep. Some even characterize the relationship on media networks as not real, contains uncertainties, and sometimes even involves lies.

Online friendship is seen as emotionally shallow. This can be explained from the perspective of $\mathrm{CMC}$ according to which the absence of non-verbal cues can reduce the warmth of the other people's presence. This is consistent with social presence theory and media richness theory (Liang \& Walther, 2015), whereas according to the social identity model of deindividuation effects (SIDE) theory, online friendship limits the transmission of interpersonal information.

Online friendship is thus a form of relationship between individuals that occurs to some people in the virtual world who use online media, such as internet applications, websites, and social media such as Facebook, Instagram, Twitter, and so forth. In this case, online friendship can be an extension of face-to-face friendship or friendship between friends known through the virtual world. The interactions between individuals include sharing, voluntariness, companionship, and mutual support (Helmi et al., 2017).

The purpose of the online friendship is not to get quality relationships but rather to share knowledge and information, build new networks (to make new friends), stay connected with friends (old acquaintances), or simply in the name of curiosity. When either party in the relationship between individuals feels disrespected, the technology can break the relationship. This would be very difficult to occur in face-toface friendship, as explained by the social enhancement hypothesis (Valkenburg \& Peter, 2007), that the lack of non-verbal cues in the internet-mediated friendship allows individuals to disclose their feelings and thoughts more openly compared to face-toface friendship. Such a self-disclosure, however, leads to information and 
experience sharing rather than sharing deeper feelings. This is reflected in the items concerning the sharing of knowledge. Self-openness also provides space to establish positive, reciprocal social interactions from which the individuals will experience a sense of mutual support.

The online friendship scale (Helmi et al., 2017) was constructed with 3rdsemester university students as the subjects. Developmentally, these students have passed the identity-seeking period, and are solidifying their identity. As for senior high school students, they are in the process of searching for identity In their search for identity, many people engage in the identity exploration, including those people who are previously strangers and then become friends in the virtual world. Unlike friendship where the communications occur via private channels that allow a quality friendship to form, quantity is the priority in online friendship rather than quality because the communications occur through public channels.

The increasing number of internet users in Indonesia accelerates the exploration of friends on social networks from year to year. According to the results of a survey by Asosiasi Penyelenggara Jasa Internet Indonesia ([APJII], the Indonesian Internet Service Providers Association) and We Are Social, in 2020, 64\% of Indonesia's population has used the Internet (APJII, 2018; Kemp, 2020). The use of the Internet will accelerate access to social networks or Social Networking Service (SNS) that bridge the relationships between individuals (Davis, 2012).

The social media in SNS which are at the top ranks in terms of usage intensity, are Instagram, Facebook, Youtube, Whatsapp, Tiktok, Snapchat, and Twitter (Kemp, 2020). The largest internet users are teenagers, especially those aged between 15 and 19 years (APJII, 2018). This means that the group of senior high school and college students is the top rank users.

Developmentally, senior high school students are in the adolescence stage. The development of identity during adolescence and early adulthood does persist throughout their life (Cox \& McAdams, 2012). According to Erikson, during the adolescence stage adolescents may experience a crisis of identity achievement vs. identity diffusion. Identity achievement is a condition that a teenager can make conscious life decisions for their future. This is possible when they can recognize and identify themselves. When they fail to do so, they will experience identity diffusion during the identity crisis (Santrock, 2013).

When adolescents commit to selfexploration, they are said to be in a moratorium condition to get an achievement. If the teenager has not reached such a commitment, they will experience diffusion. This identity search process will continue from period to period in a moratorium-achievement-moratoriumachievement (MAMA) cycle. This cycle explains that solving an identity crisis during adolescence only guarantees that the next identity crisis will be faced (Marcia, 1994).

When an adolescent can pass through these identity crises, they will enter the early adulthood stage. In the MAMA cycle, an adolescent may experience an identity foreclosure, that is when they are in 
a moratorium condition and take other people's commitments in their life. If this is applied to online friendship, the widespread interactions on social networks, even cross-national borders, may lead to an identity foreclosure to adolescents. It can thus be said that if a high school student who is in the adolescent stage can successfully go through the MAMA cycle and reach an identity foreclosure, the clarity of identity will be achieved and the activities they do in the virtual world will continue into early adulthood.

From the above descriptions, the Online Friendship Scale that was originally constructed with university student subjects was considered applicable to senior high school students with good psychometric properties support.

\section{Method}

The research method used to test the measurement model was a quantitative method by distributing the online friendship scale. Since the testing of the measuring instrument required many subjects, some experts might consider it as a survey method.

\section{Subjects}

The subjects of this present study were 214 male and female students in a public high school in Yogyakarta with some characteristics, including being 10th or 11th graders, having social media account(s), and being willing to become research subjects.

\section{Measuring instrument}

The measuring instrument used in this study was the online friendship scale developed by Helmi et al (2017). The scale was constructed with university students as the subjects. This scale consists of 4 aspects, namely sharing, voluntariness, mutual support, companionship.

\section{Psychometric properties testing}

To assess the validity and the reliability of the instrument, psychometric properties testing was carried out, including validity and reliability testing. In this study, the analysis of the psychometric properties used a classical test theory (CTT) approach with the confirmatory factor analysis (CFA) method to generate the construct and construct reliability values. Besides, the CFA also resulted in factor loading for each item and its aspects, average variance extracted (AVE) value, and goodness of fit indices, which were used as evidence of the construct validity of this measurement.

\section{Results}

Before doing the analysis, several assumptions were checked, namely: outliers, multivariate normality, multicolinearity, and singularity.

Outliers (Mahalanobis distance). The outliers in the structural modeling analysis were detected through the Mahalanobis distance chi-square value. The standard value for a subject to be classified as an outlier is when the Mahalanobis distance value is above the limit value obtained from the predetermined probability and degree of freedom values of the model (Ghozali, 
2017). The standard value based on the degree of freedom of 100 and a predetermined probability of 0.05 was 124.342. Meanwhile, the highest Mahalanobis distance score was 68.211 and obtained by 232 subjects. This means that there were no subjects who were outliers in the analysis.

Multivariate normality. The normality testing was carried out to see whether the distribution of each item formed a normal curve and checked the multivariate data to ensure that the multivariate data were normally distributed. Ghozali (2017) stated that an item's CR value on skewness that exceeds 2.58, either positive or negative, indicates that the item is not normally distributed. Likewise, if the CR value of the multivariate exceeds that set value, it is considered not normally distributed. The $\mathrm{CR}$ value of the multivariate in this research model was 23.474 and thus can be said that the multivariate model is not normally distributed.

Multivariate data that are not normally distributed would impact the estimator of analysis. Asparouhov and Muthén (2005) suggest that to analyze a model that is not normally distributed; the MLR (Maximum Likelihood Robust) estimator has good capabilities. Therefore, in this analysis, the estimator used was the Maximum Likelihood Robust (MLR).

Multicollinearity and singularity. The multicollinearity and singularit.y were tested to see the covariance between items and the latent variables formed through the covariance matrix. According to Schumacker and Lomax (2016), multicollinearity and singularity can be seen from the condition number $(\mathrm{CN})$ value in the covariance matrix. Smaller $\mathrm{CN}$ values indicate higher multicollinearity. The $\mathrm{CN}$ value in the model built in this study was 34.194, which is quite far from 0 so that it can be said that there were no multicollinearity and singularity issues.

\section{Model testing}

The results of the model testing can be seen in Figure 1, whereas the scale's reliability as shown by Cronbach's alpha coefficient was 0.814 .

Based on the results of construct validity and reliability analyses, it can be said that the Online Friendship Scale has good psychometric properties support with the greatest contributions come from companionship, followed by voluntariness, sharing, and mutual support.

\section{Discussion}

Figure 1 suggests that this model's parameter values meet the set standards. According to Ghozali (2017), the normed chi-square must be at a value of 2.00 or lower, CFI and TLI must be 0.90 or higher, RMSEA must be below the 0.08 tolerance limit and the probability is insignificant. The chi-square parameter does not have a set standard benchmark but smaller the chisquare values are expected (Furr \& Bacharach, 2013). However, according to Furr and Bacharach (2013), the probability value can be ignored because this parameter is very sensitive to a large number of subjects; the number of subjects in this present study was 232 . 
Figure 1 also shows that each of all items has a factor loading value of above 0.4 , the minimum limit set to say that an item is a good item or contains the underlying aspect (Furr \& Bacharach, 2013). Besides, on the second-order, every aspect also has a high loading factor, i.e. greater than 0.7 .

In confirmatory factor analysis, items in a measurement construct must converge or have high variance portions to get a good convergent validity as indicated by the Average Variance Extracted value (AVE; Ghozali, 2017). The AVE value of this scale model was 0.727, while Ghozali (2017) suggests that an AVE value greater than 0.5 indicates a good convergent validity. Thus, the measurement of online friendship is said to have good convergent validity based on the average variance extracted.

Construct reliability is also one of two indicators of convergent validity in addition to the average variance extracted (Ghozali, 2017). As for the Online friendship measure, the construct validity value was 0.913. According to Ghozali (2017), a $C R$ value above 0.7 indicates good construct reliability. Thus, this efficacy measurement is said to have a good convergent validity based on the AVE and $\mathrm{CR}$ values.

Based on the results of the analysis above, it can be said that the Online friendship scale can be applied to high school students as it received empirical support for its psychometric properties.
Developmentally, high school students are generally in the adolescence stage. From Erikson's theory, the adolescents enter the fifth stage of development, namely "identity vs role confusion." Self-exploration includes finding out who they are, searching for identity, and figuring out where their life is going. When an adolescent can healthily explore themselves and live their life positively, they will achieve a positive identity and not experience identity confusion (Santrock, 2013).

In the context of online friendship, in Helmi et al. (2017) study, university students engage in high self-exploration by exploring the virtual world and making friends with people who could be initially strangers to them. The exploration by making friends either for social comparison purposes or simply for forming "challenging" interpersonal relationships continues from high school to college. This is consistent with the results of Tanoto's (2020) study that the online friendship for high school students mostly aims at expanding friendship, including making new friends, finding close friends, staying connected with friends from other countries or other cities, and getting informed of many people. Making friends with people from other countries can serve as a selfvalidation that one's social network is extensive and may result in pride. 


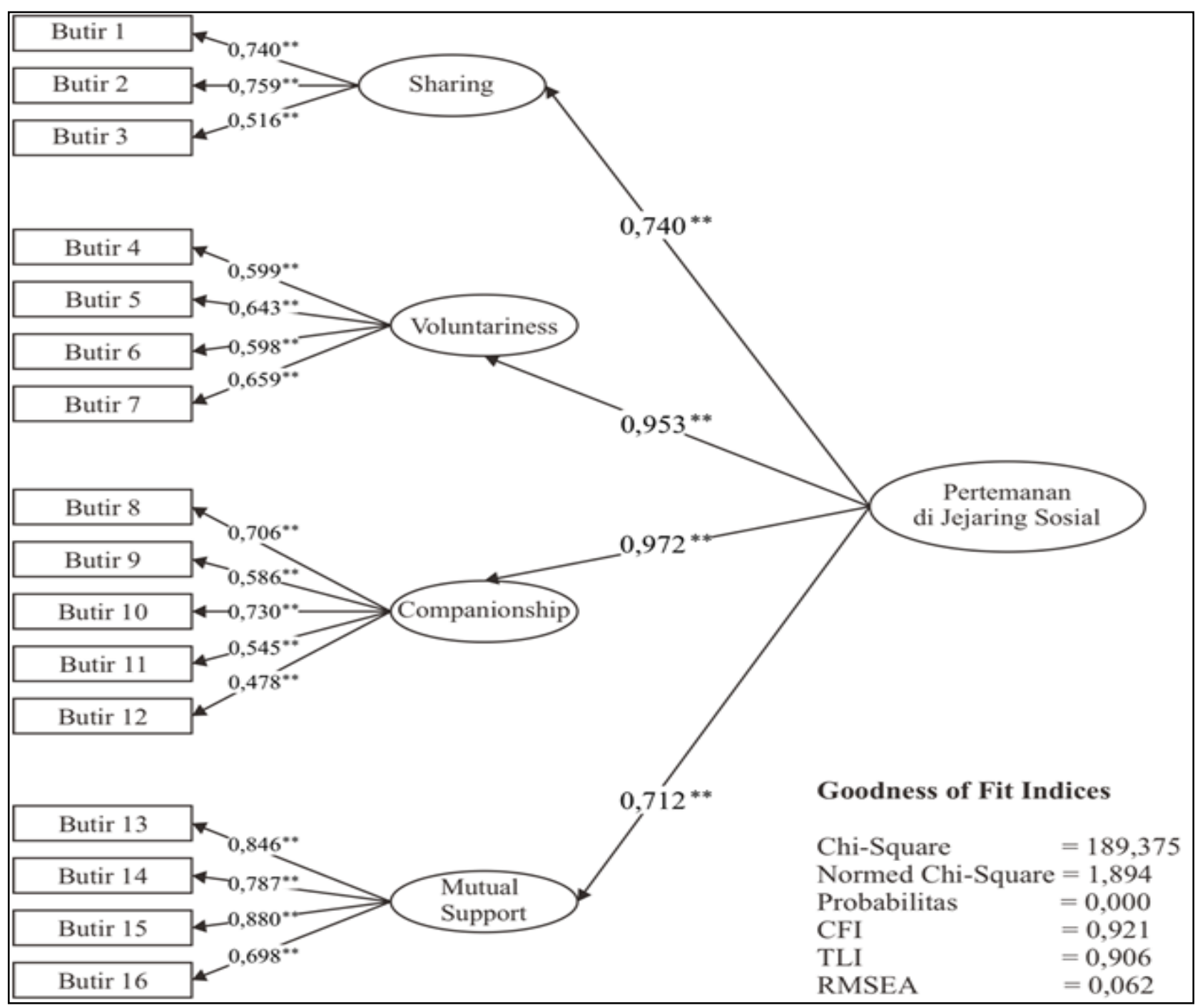

Note. Butir = item; Pertemanan di Jejaring Social = Online Friendship

Figure 1. Results of the CFA testing of the Online Friendship Scale Model

Companionship had the greatest contribution to high school students on the online friendship scale. Companionship includes doing activities together with peers and comfortable communication between them. Again, for high school students, this is due to the need to expand the network of friends. Doing activities together and compatible communication will build companionship (Tanoto, 2020). This is a forerunner to an increase in the quality of friendship, an increase in closeness and intimacy, although it might not as deep as what happens in face-to-face friendships. This is in line with the enhancement hypothesis (Valkenburg \& Peter, 2007) that CMC increases the likeliness of deep interactions but with a lower quality compared to face-to-face interaction. This happens because it does not open communication space through private channels but limited to public channels only.

The second highest contribution was from voluntariness, which is the freedom to have or not to have relationships with 
friends. This works with university students subject to whom volunteerism is an essential component to make friends in life.

The findings of Tannos's (2020) study shows that online friendship in high school students is characterized by sharing, including sharing experiences, opinions, and knowledge. This explains the finding of the use of Helmi and colleagues' online friendship scale (2017) that sharing is the behavior shown by most university students. This suggests sharing behavior during high school continues to college. Sharing is an important behavior in making friends on social networks. This is facilitated bythe speed and ease of sending and receiving messages even to large numbers of people at the same time. This sharing behavior on social networks is essentially knowledge sharing: receiving knowledge from and sending knowledge to others (Helmi, 2010).

In terms of socio-emotional development, during adolescence, high school students begin to feel the need for the presence of peers in their environment. Social support from friends greatly affects individual wellbeing (Santrock, 2013). The online friendship scale also contains a mutual support aspect, which is reciprocal supports from reciprocal social interactions and positive interactions that lead to a sense of mutual support. If the relationship is felt to be unpleasant, it can be broken technologically. It is easier to break up an online friendship than a face-to-face friendship when discomfort or conflict occurs. In face-to-face friendship, being rejected or ostracized by friends likely cause problems in one's friendship in general, and can even lead to more serious problems such as juvenile delinquency, drug abuse, and depression (Rice \& Dolgin, 2008).

Meanwhile, the quality of online friendship will increase with increased selfdisclosure. This is in line with Wang et al. (2014) and Pang (2018) that the quality of friendship increases with mutual trust. The quality of friendship is reflected in satisfaction, closeness, brotherhood, comfort, and help (Tian, 2011).

The private communication channels on social networks provide the opportunity for a higher level of friendship quality and closeness than the public channels (Chan, 2020). However, the online friendship scale does not reveal communication via private channels, indicating that the quality of online friendship is not as optimal as that of faceto-face friendship; it is limited to companionship through their public features. This also indicates that the quality of friendship enhancement may also occur but not as high as what happens in face to face interactions (Valkenburg \& Peter, 2007).

\section{Conclusion}

From the MAMA cycle point of view, the adolescent subjects in this present study have successfully passed the identity crisis and obtained various achievements. This is possible because they engage in interpersonal relations in social networks where regional and national boundaries are no longer existent, so there is a greater chance of experiencing identity foreclosure. It is not surprising that the activities the high school student subjects do in the social 
networks are what their university student counterparts do in social networks in their early adulthood. It can be concluded that this present study found empirical evidence of good psychometric properties in the online friendship scale in high school students.

\section{Suggestion}

We extend this study in different life span to explore a potential online friendship framework for future research. It is also possible to explore development tasks in online environment. These studies become more significant because people are suggested to stay at home and to interact virtually.

\section{References}

Asosiasi Penyelenggara Jasa Internet Indonesia [APJII]. (2018). Hasil survei penetrasi dan perilaku pengguna internet Indonesia 2018 [Result of penetration and behavioral profile of internet users in Indonesia survey]. APJII, 51. Retrieved from

https://apjii.or.id/survei2018

Asparouhov, T., \& Muthén, B. O. (2005). Multivariate statistical modeling with survey data. In Proceedings of the Federal Committee on Statistical Methodology (FCSM) Research Conference (pp. 1-30).

Chan, D. K. S., \& Cheng, G. H. L. (2004). A comparison of offline and online friendship qualities at different stages of relationship development. Journal of Social and Personal Relationships, 21(3), 305-320. doi: https://doi.org/10.1177/026540750404 $\underline{2834}$

Chan, G. H. (2020). Intimacy, friendship, and forms of online communication among hidden youth in Hong Kong. Computers in Human Behavior, 111, 116.

doi:

https://doi.org/10.1016/j.chb.2020.10 $\underline{6407}$

Cox, K. \& McAdams, D. P. (2012). The transforming self: Service narratives and identity change in emerging adulthood. Journal of Adolescent Research, 27(1), 18-43. doi: https://doi.org/10.1177/074355841038 $\underline{4732}$

Davis, K. (2012). Friendship 2.0: Adolescents' experiences of belonging and self-disclosure online. Journal of Adolescence, 35(6), 15271536.

doi:

https://doi.org/10.1016/j.adolescence .2012 .02 .013

Furr, M. R., \& Bacharach, V. R. (2013). Psychometrics: An introduction (2nd ed.). New York: SAGE Publisher.

Ghozali, I. (2017). Model persamaan struktural dengan AMOS 24 [Structural equation modeling with AMOS 24] (7th ed.). Semarang: Badan Penerbit Universitas Diponegoro.

Helmi, A.F (2010). Model determinan perilaku inovatif [Determinant model of innovative behavior] (Unpublished doctoral dissertation). Faculty of Psychology, Universitas Gadjah Mada, Yogyakarta.

Helmi, A. F., Widhiarso, W., \& Husna, A. N. (2017). The development of online friendship scale. International Journal of Cyber Behavior, Psychology and 
Learning, 7(4), 12-25. doi: https://doi.org/10.4018/IJCBPL.20171 $\underline{00102}$

Kemp, S. (2020). Digital 2020: 3.8 billion people use social media. Retrieved May 17, 2020 from https://wearesocial.com/blog/2020/0 1/digital-2020-3-8-billion-peopleuse-social-media

Liang, Y. J., \& Walther, J. B. (2015). Computer mediated communication. In J. D. Wright, International Encyclopedia of the Social \& Behavioral Sciences (2nd ed.) (pp. 504-509). doi: https://doi.org/10.1016/B978-0-08097086-8.95090-6

Marcia, J. E. (1994). Ego identity and object relations. In J. M. Masling \& R. F. Bornstein (Eds.), Empirical perspectives on object relations theory (p. 59-103). American Psychological Association. doi: https://doi.org/10.1037/11100-003

Pang, H. (2018). Microblogging, friendship maintenance, and life satisfaction among university students: The mediatory role of online selfdisclosure. Telematics and Informatics, 35(8), 2232-2241. doi: https://doi.org/10.1016/j.tele.2018.08. $\underline{009}$

Rice, F. P., \& Dolgin, K. G. (2008). The adolescent: development, relationships, and culture (12th ed.). Boston, MA: Allyn and Bacon.

Santrock, J. W. (2013). Life-span development (14th ed.). New York: McGraw-Hill.

Schumacker, R. E., \& Lomax, R. G. (2016). A beginner's guide to structural equation modeling (4th Ed.). New York: Routledge.
Tannos, J. J. (2020). Hubungan antara kecemasan sosial dengan pertemanan remaja di jejaring sosial [Relationship between social anxiety and adolescent friendship in social network] (Unpublished bachelor's thesis). Faculty of Psychology, Universitas Gadjah Mada, Yogyakarta.

Tian, Q. (2011). Social anxiety, motivation, self-disclosure, and computermediated friendship: A Path analysis of the social interaction in the blogosphere. Communication Research, 40(2), 237-260. doi: https://doi.org/10.1177/009365021142 $\underline{0137}$

Wang, J. L., Jackson, L. A., Gaskin, J., \& Wang, H. Z. (2014). The effects of Social Networking Site (SNS) use on college students' friendship and well-being. Computers in Human Behavior, 37, 229-236. doi: https://doi.org/10.1016/j.chb.2014.04. $\underline{051}$

Wismabrata, M. H. (Ed.) (2020, February 14). Marak kasus "bullying" di sekolah: Ada yang hilang dari pelaku [The many bullying cases at school: Something is missing in the perpetrators.]. Kompas.com. Retrieved from https://regional.kompas.com/read/2 020/02/14/05150001/marak-kasusbullying-di-sekolah-ada-yanghilang-dalam-diripelaku?page=all\#page2

Valkenburg, P. M., \& Peter, J. (2007). Online communication and adolescent well-being: Testing the stimulation versus the displacement hypothesis. 
ONLINE FRIENDSHIP SCALE, FIT, HIGH SCHOOL STUDENTS

Journal of Computer-Mediated Communication, 12(4), 1169-1182. doi: https://doi.org/10.1111/j.10836101.2007.00368.x

Yeung, G., \& Fung, H. (2007). Social support and life satisfaction among
Hong Kong Chinese older adults: family first? European Journal of Ageing, 4(4), 219-227. doi: https://doi.org/10.1007/s10433-007$\underline{0065-1}$ 